\title{
Determining the Sale Price of Madura Cow in Gayam Sub- District Using Activity Basic Cost (Abc) Method
}

\author{
Very Andrianingsih*, Dessy Novitasari Laras Asih \\ Faculty of Business and Economics, Management, Wiraraja University, Indonesian
}

*Corresponding Author: Very Andrianingsih, Faculty of Business and Economics, Management, Wiraraja University, Indonesian

\begin{abstract}
Sumenep is a district in East Java that has the largest cattle population. Among them is Gayam District which has a high cattle population. Madura cattle population in Gayam Subdistrict, Sumenep Regency is increasing continuously. This phenomenon is an opportunity for the community around Gayam District. This opportunity can be used as a business for them to raise the economy from their cattle business. The purpose of this study is to analyze and determine the determination of the cost of sales of Madura cattle in Sapudi Island, Gayam District, Sumenep Regency. The stages carried out in this study started from preparation to approach all respondents. The next stage is to collect data from respondents through questionnaires that are distributed and accompanied by in-depth interviews to get answers that meet the needs of the researcher. The last stage is to analyze and present the overall research results using the Activity Basic Costing $(A B C)$ method. The expected output is the publication of articles in the ISSN Sinta National Journal 4 Economic Forum of Mulawarman University in 2019 and proof of the Level of Technology Readiness (TKT) on a scale of 2.
\end{abstract}

Keywords: Activity Basic Costing, HPP, Madura Cattle

\section{INTRODUCTION}

Indonesia is the world's largest archipelago consisting of 17,504 islands. Indonesia is one of the three largest countries with a diversity of flora and fauna. The distribution of flora and fauna is influenced by several things, such as climate, soil, the shape of the earth's surface, and factors from other living things. Based on the region and the characteristics of the flora and fauna, it can be divided into three parts, namely West, Central and Eastern Indonesia. The distribution of Fauna in the eastern part of Indonesia is also known as the Sahul Shallow Area. The types of fauna in eastern Indonesia are of the Australis type or are like the types of fauna that live similar to the fauna in Australia. Endemic animals in the eastern region such as the Komodo dragon, anoa, or hog deer.

Cows are livestock that are raised primarily for consumption. Apart from meat, cows also produce milk which has a protein source, skin to make shredded, offal, and feces that can also be processed into gas for stoves and manure. Currently, cattle are one of the most superior commodities in several countries, including Indonesia. Livestock is the activity of breeding and cultivating livestock to get the benefits and results of these activities.The development of the livestock sector is one form of development to achieve the welfare of the breeders and their ability to drive overall economic growth. Cattle breeders can assist the government in increasing beef production, especially by providing quality beef according to the people's ability or purchasing power, so that beef prices are more controlled. The prospect of developing beef cattle in Indonesia is still wide open. The cattle population in Indonesia is concentrated on the islands of Java, Sulawesi and Bali. One of them is on the island of Madura. The geographical characteristics of the island of Madura, which are mostly hilly, rocky, and in the form of dry land are one of the determining factors that Madura cattle are the dominant commodity in the farming system in the Madura Island region.

Sumenep Regency is one of the districts on Madura Island which is noted to have the potential for developing beef cattle. Madura cow center in Sumenep Regency is located on Sapudi Island which consists of two districts, namely Gayam District and Nonggunong District. According to data from the Livestock Service Office of Sumenep Regency in 2019, the population of beef cattle in Sumenep Regency reached 367,362 cows. It is a district with the highest beef cattle population in East Java. 
The government has planned Sapudi Island as an area for the purification of Madurese cattle (Winarso, 2016). This is done so that the population and purity of the Madura cows are maintained.

Increasing the number of cattle population in Gayam District is one means of increasing community income. Increasing the economy of Madurese cattle breeders can be started from determining the costs involved in determining the selling price. Therefore, from the profit earned, it is considered able to help increase the income of Madura cattle breeders in Gayam District. Based on this phenomenon, a research can be carried out entitled "Determining the Selling Price of Madura Cattle in Gayam District with theMethod Activity Basic Cost". The purpose of this study is to analyze and determine the selling price determination of Madura cattle in Gayam District. The urgency of this research is to study cattle breeders in improving their economy by determining the selling price of Madura cattle in Gayam District.

\section{LITERATURE REVIEW}

a. Costs

According to Firdaus A, et al (2019) costs are expenses or the value of sacrifices made to obtain goods or services that are useful in the future. Classification of costs according to the relationship between costs and something being financed can be grouped into two groups, namely direct costs and indirect costs

\section{b. Profit}

The definition of profit in general is the difference from income over expenses within a certain period of time. Profit is income between income and expenses, if the income exceeds expenses, the result is net income (Marsiwi and Walfirotin 2015). Profit can be used as a measure of efficiency and effectiveness in a work unit because the main objective of establishing a company is to get the maximum profit in the short and long term.

\section{c. Cost of Capital}

Cost of capital is the minimum level of income required by the owner of capital. The company's cost of capital is one of the benchmarks for assessing whether management's spending decisions are optimal decisions. The cost of capital is also important to assess the feasibility of an investment proposal depending on the method required (Sudana, 2009).

\section{d. Madura}

Cattle Madura cattle are native cows that are bred without cross from other cows. Hartati and Soewandi (2020) argue that Madura Cattle is one of the local beef cattle that has high adaptability to the influence of tropical environments and is one of the local germplasm that must be preserved and its genetic potential must be developed.

\section{e. Cost of Goods Sold (HPP)}

A more precise determination of production costs will be able to produce a more accurate cost of production (Satria, 2017). The elements in the cost of production are direct raw material costs, direct labor costs, and factory overhead costs. There are two approaches used to calculate the cost of goods manufactured, namely the full costing method and themethod variable costing (Arizal and Tukasno, 2018).

\section{f. Cost Classification}

According to Firdaus A, et al (2019) cost classification is useful for informing and presenting costs for management for decision-making purposes. There are several types of costs based on behavior, namely: variable costs, fixed costs, and semivariable costs. In the classification of costs, the concept of "various costsknownfor different purposes is." Therefore, the method of classifying costs is based on the concept of what the costs are grouped for.

\section{g. Activity Basic Costing (ABC)}

Activity based costing is basically related to determining product costs that impose costs on products or services based on resource consumption by activities (Suwirmayanti and Putu, 2018). The HPP calculation using the $\mathrm{ABC}$ method is more accurate in calculating the cost of goods manufactured and 
in determining the selling price of the product. Three stages in the design of the Activity Based Costing (ABC) System, namely:

1) Identify the cost of sources of funds and activities

2) Charge resources to activities

3) Assign activity costs to cost object

\section{RESEARCH METHODS}

This research uses quantitative methods, namely the Activity Basic Costing (ABC). ABC is usually used for pricing. The data in this study were obtained from cattle breeders in Sapudi Island, Gayam District, Sumenep Regency. The data sources used were primary (questionnaire) and secondary (references and literature) data sources. The population of this research is all cattle breeders in Sapudi Island, Gayam District, Sumenep Regency. Determination of the sample using purposive sampling. The criteria used are: Madura cattle ownership ranges from 5-10 heads, have sold cows, have at least 5 years of experience. The number of samples used in this study were 50 respondents. Data Collection Techniques are interview (interview). Conducted with cattle breeders with regard to costs, questionnaire (questionnaire). In the form of several questions and respondent profiles, Observation that using direct observation at the research location about the situation and conditions that occur in the field.

The data that will be obtained from respondents are information regarding overhead costs, production costs, labor costs, cost of goods manufactured, activity costs, resource costs. The method of analysis used in this study is ABC. ABC is used to determine the cost of goods sold for Madura cattle in Gayam District. The stages of analysis carried out in this study are, spread the questionnaire, make observations, calculating costs such as BBB, BTKL, and BOP. And then imposing activity costs on objects which then determine the results and conclusions for the selling price of Madurese cattle.

\section{RESULTS AND DISCUSSION}

The success of the cattle business to improve the economy in Gayam District is determined by several factors and several characteristics of the breeders (respondents). The characteristics of the respondents were influenced by age, education level, and farming experience. Based on the data obtained, the age of the respondents was in the range of 32-72 years. The age grouping of respondents is described in Table 1 as follows:

Table1. Age grouping of respondents

\begin{tabular}{|l|l|l|l|}
\hline No & Age Group (Years) & Number of breeders (people) & Percentage (\%) \\
\hline 1. & $31-40$ & 2 & 4.00 \\
\hline 2. & $41-50$ & 15 & 30.00 \\
\hline 3. & $51-60$ & 10 & 20.00 \\
\hline 4. & $61-70$ & 17 & 34.00 \\
\hline 5. & $\geq 70$ & 6 & 12.00 \\
\hline & TOTAL & $\mathbf{5 0}$ & $\mathbf{1 0 0 . 0 0}$ \\
\hline
\end{tabular}

In addition, education also affects the decision making of a person or farmer breeder in developing their business. The level of education can support a farmer breeder in utilizing existing technology to improve his farming. The following is the grouping of respondents according to their education level (table 2).

Table2. Classification of Respondents' Education Level

\begin{tabular}{|l|l|l|l|}
\hline No & \multicolumn{1}{|c|}{ Education } & \multicolumn{1}{|c|}{ Number of Farmers (people) } & Percentage (\%) \\
\hline 1. & SD & 37 & 74.00 \\
\hline 2. & SMP & 8 & 16.00 \\
\hline 3. & SMA & 5 & 10.00 \\
\hline & TOTAL & $\mathbf{5 0}$ & $\mathbf{1 0 0 . 0 0}$ \\
\hline
\end{tabular}

The results of the data obtained in the field using a questionnaire are known that most of the respondents only received primary school education.

Table3. Experience Raising

\begin{tabular}{|l|l|l|l|}
\hline No. & Raising Experience (years) & Number of Breeders(person) & Percentage (\%) \\
\hline 1 & $1-5$ & 0 & 00,00 \\
\hline 2. & $6-10$ & 23 & 46.00 \\
\hline
\end{tabular}


Determining the Sale Price of Madura Cow in Gayam Sub-District Using Activity Basic Cost (Abc) Method

\begin{tabular}{|l|l|l|l|}
\hline 3. & $>10$ & 27 & 54.00 \\
\hline & TOTAL & $\mathbf{5 0}$ & $\mathbf{1 0 0 . 0 0}$ \\
\hline
\end{tabular}

The experience of raising cattle is also a factor that triggers the success of increasing cattle. People who have longer farming experience will of course better understand the needs of cattle to produce the best quality cattle.

There are several factors that make someone decide to raise cattle. One of them is that it can be used as an investment in the future. From an observation with 50 respondents in Gayam District, on average each person owns 6 cows. There are several things that must be fulfilled in raising cattle, including cages, equipment, feed (grass), medicine (vaccines, vitamins), and labor.

\subsection{Raw Material Costs}

Table4. Feed Costs

\begin{tabular}{|l|l|l|}
\hline No & Feed & Total costs (per day) \\
\hline 1. & Field Grass & IDR 1,700 \\
\hline 2. & Rice or Corn Waste & IDR 4,000 \\
\hline 3. & Factory Waste (tofu dregs) & IDR $2,000 / \mathrm{kg}$ \\
\hline & Total cost & IDR 7,700 \\
\hline
\end{tabular}

The average consumption of field grass for one cow per day is IDR 3,000. For concentrate, the price of 1 kilo gram is IDR 2,000, and agricultural waste (rice or corn) for one cow is IDR 4,000. The total cost of feed for one cow is IDR 7,700.

\subsection{Direct Labor Costs}

Table5. Labor Costs

\begin{tabular}{|l|l|l|}
\hline NO & Description & Total Costs (per day) \\
\hline 1. & Feeding wages & IDR 10,000 \\
\hline 2. & Wages for cleaning the cage & IDR 15,000 \\
\hline & Total Cost & IDR 25,000 \\
\hline
\end{tabular}

Most of the cattle in Gayam District are managed by themselves or their families. The cost incurred for feeding is IDR 10,000 per day. The cost required to clean the cage is IDR 15,000. So the total cost of labor for cattle is IDR 25,000 / day.

\subsection{Production Overhead Costs (BOP)}

Table6. Average Fixed Costs of Madura Cattle

\begin{tabular}{|l|l|l|}
\hline No & Information & Total costs (per year) \\
\hline 1. & Construction of a cage & IDR 7,850,000 \\
\hline 2. & Cage depreciation & IDR 688,000 \\
\hline 3. & Equipment & IDR 107,000 \\
\hline & Total Cost & IDR 8,645,000 \\
\hline
\end{tabular}

The cowsheds owned by breeders in Gayam District are mostly tiled or permanent cages. While the others still have dirt floors. Per year the depreciation cost of the cage is less than $10 \%$, which is IDR 688,000 . The initial cost for the purchase of the tool, the farmer spends an average of IDR 107,000 for the economic life of the tool for approximately 4 years.

Table7. Average Variable Costs of Madura Cattle

\begin{tabular}{|l|l|l|}
\hline No & Information & Total costs \\
\hline 1. & Electricity and water & IDR 27,000 \\
\hline 2. & Vaccines / vitamins & IDR 100,000 \\
\hline 3. & Change of rope (tongar) & IDR 78,000 \\
\hline & Total Cost & IDR 205,000 \\
\hline
\end{tabular}

The cost for electricity and water is IDR 27,000. Vaccines are given annually and some even once every three months. The cost of giving vaccines for one cow is IDR 100,000. The fee for changing the rope is IDR 78,000. Change the rope every year.

\subsection{Design of System Activity Basic Costing (ABC)}

The cost calculation using the Activity Basic(CostingABC) system is considered more accurate when compared to the cost calculation using the traditional system. This is because in the ABC system 
calculation all costs incurred for a product are clearly detailed based on activities in the production process.

\subsection{FIRST STAGE: Identification of costs of funding sources and activities}

From the data obtained above, there are several activities that are included in overhead activities, namely as follows: Feed Costs, Direct Labor Costs, Cage Making Costs, Cage Depreciation Costs, Rope Change Costs, Equipment Costs, Electricity and Water Costs, Vaccine Costs.

In the $\mathrm{ABC}$ (Activity Based Costing) system, the resulting product does not directly consume resources but absorbs activity. These activities that use resources directly.

SECOND STAGE: Charging Resource Table8. Classification of Activity

\begin{tabular}{|l|l|l|}
\hline \multicolumn{1}{|c|}{ Activity } & \multicolumn{1}{c|}{ Level } & \multicolumn{1}{c|}{ Total } \\
\hline Feed & Unit & IDR2,810,500 \\
\hline CostsDirectLabor & Batch & IDR $9,125,000$ \\
\hline Cost of MakingCages & Facilities & IDR 7,850,000 \\
\hline Cost of Depreciation ofCages & Facility & IDR 688,000 \\
\hline Costs to ChangeStraps & Facility & IDR 78.000 \\
\hline Equipment costs & Unit & IDR 107.000 \\
\hline Cost of Electricity and Water & Unit & IDR 27.000 \\
\hline Vaccine cost & Unit & IDR 100,000 \\
\hline
\end{tabular}

Based on the table above can be explained classification costs by activity :

a. Unit level activity. Feed costs, equipment costs, electricity and water costs, and vaccine costs

b. Batch level activity.Indirect labor costs

c. Facility level activity. The cost of making the cage, the cost of shrinking the cage, and the cost of changing the rope.

\subsection{THIRD STAGE: Assign activity costs to cost objects}

The costs for each activity obtained in the second stage are then charged to the product, according to the activities that the product has gone through. The following is the calculation of the HPP for cattle.

Table9. HPP Cattle

\begin{tabular}{|l|l|}
\hline Type Cost & Total Cost / Cattle \\
\hline Raw Material Costs & IDR 2.810 .500 \\
\hline Direct Labor Costs & IDR 9.125 .000 \\
\hline Overhead Costs Production & IDR 8.850 .000 \\
\hline HPP & IDR 20.785.500 \\
\hline
\end{tabular}

The table shows the calculation result of the HPP for one cow is IDR 20,785,500. The results of interviews with respondents in Gayam Subdistrict who have sold cows, with prices ranging from IDR $10,000,000$ to IDR 15,000,000. From these data it can be seen thatoccurs undercosting HPPwhen compared with the $\mathrm{ABC}$ method. The thing that causes undercosting is the mindset of the people who only see the benefits by comparing the buying and selling prices.

\section{CONCLUSIONS AND SUgGeSTIONS}

\subsection{Conclusion}

Based on the results of the research that has been done, it can be seen that the determination of the cost of goods manufactured using the ABC system (activity based costing) occurs undercosting. Which is where from the results of observations of the people of Gayam District, it is known that the sale of one cow ranges from IDR 10,000,000 to the highest price of IDR 15,000,000. The calculation of the cost of goods manufactured using the ABC system (activity based costing) by accumulating overhead costs, raw material costs, and direct labor costs, the calculation value for one cow is IDR $20,785,500$.

\subsection{Suggestion}

The suggestions that can be submitted in this research are: 
a. Judging from the results of the research above, it is necessary to consider before selling cattle so that breeders do not experience losses.

b. Another alternative that can be done is to conduct a market survey to find out current prices and some future time. Predictions like this also make it easier to determine the selling price in order to get the desired profit (profit).

\section{REFERENCES}

[1] Dunia, Firdaus A., Abdullah, Wasilah, dan Sasongko, Catur (2019). Akuntansi Biaya Edisi 5. Salemba Empat: Jakarta.

[2] Hartati dan Soewandi (2020). "Deteksi Polimorfisme Gen Growth Hormone (Gh|Mspi) Pada Sapi Madura Yang Dipelihara Di Kandang Kelompok Loka Penelitian Sapi Potong”. Prosiding Seminar Teknologi dan Agribisnis Peternakan VII. Hal: 445-451.

[3] Kabinlapat, Panravee and Sutthachai, Siriluck (2017). An application of activity-based costing in the chicken processing industry: a case of joint products. International Food and Agribusiness Management Review. Volume 20 Issue $1: 85-98$

[4] Kustiningsih, N., Atmadja, S. S., \& Patmana, O. (2017). Implementation Of Activity Based Costing System In Making Effort To Determine The Tariff Of Operation Action (Case Study In Surabaya Royal Hospital). Archives of Business Research, 5(11), 81-93.

[5] Satria, Hendy. 2017. Penerapan Metode Activity Based Costing Untuk Menentukan Harga Pokok Produksi. Jurnal Benefita, Volume 2 No. 2 : 91-101

[6] Sudana, I. M. 2009. Manajemen Keuangan Teori dan Praktik. Surabaya: Airlangga University Press

[7] Sumenepkab.go.id . "Pemkab Sumenep Canangkan Kampung IB Di Delapan Desa". Diakses pada 06 Agustus 2019 dari (https://www.sumenepkab.go.id/)

[8] Suwirmayanti, Ni Luh Gede Pivin dan Putu Pande Yudiastra (2018). Penerapan Metode Activity Based Costing Untuk Penentuan Harga Pokok Produksi. Jurnal Sistem dan Informatika, Volume 12 Nomor 2

[9] Wafirotin, K. Z dan Marsiwi, Dwiati. 2015. Persepsi Keuntungan Menurut Pedagang Kakilima di Jalan Baru Ponorogo. Jurnal Ekulilibrium, Volume 13, Nomor 2, Maret 2015

[10] Winarso, Aji,. Satria Fadjar dan Ridwan Yusuf. 2016. Pengaruh Klimat terhadap Infeksi Nematoda Saluran Pencernaan pada Sapi Potong di Kabupaten Bojonegoro, Provinsi Jawa Timur. Jurnal Kajian Veteriner Jurnal Kedokteran Hewan Indonesia ISSN: 2356-4113; EISSN: 2628-6021 Volume 4 No. 1 Juni 2016

Citation: Very Andrianingsih, Dessy Novitasari Laras Asih. "Determining the Sale Price of Madura Cow in Gayam Sub-District Using Activity Basic Cost (Abc) Method" International Journal of Managerial Studies and Research (IJMSR), vol 8, no. 9, 2020, pp. 18-23. doi: https://doi.org/10.20431/2349-0349.0809003.

Copyright: () 2020 Authors. This is an open-access article distributed under the terms of the Creative Commons Attribution License, which permits unrestricted use, distribution, and reproduction in any medium, provided the original author and source are credited. 